\title{
The completeness of Kant's metaphysical exposition of space
}

\author{
by Henny Blomme, Paris/Wuppertal
}

\begin{abstract}
In the first edition of his book on the completeness of Kant's table of judgments, Klaus Reich shortly indicates that the B-version of the metaphysical exposition of space in the Critique of pure reason is structured following the inverse order of the table of categories. In this paper, I develop Reich's claim and provide further evidence for it. My argumentation is as follows: Through analysis of our actually given representation of space as some kind of object (the formal intuition of space in general), the metaphysical exposition will show that this representation is secondary to space considered as an original, undetermined and as such unrepresentable intuitive manifold. Now, following Kant, the representation of any kind of object involves diversity, synthesis and unity. In the case of our representation of space as formal intuition, this involves, firstly, a manifold a priori, i.e. space as pure form, delivered by the transcendental Aesthetic, secondly, a figurative, productive synthesis of that manifold, and, thirdly, the unity provided by the categories. Analysing our given representation of space - the task of the metaphysical exposition - amounts to dismantling its unity and determine its characteristics with respect to the categories.
\end{abstract}

Keywords: Metaphysical Exposition, Transcendental Aesthetic, Klaus Reich, Formal Intuition, Form of Intuition, Categories

Compared to the transcendental Logic, the transcendental Aesthetic certainly counts as the more controversial part of Kant's first Critique. For a long time, the view that the Aesthetic is a mere patchwork of precritical views and not entirely thought-through arguments, had almost become standard, and only in recent years has it been substantially discarded by Kant-scholars defending Kant's transcendental Aesthetic as the most original part of his philosophy. Although it can seem strange to characterise this section of 40 pages (within a total of 884 for the second edition) as the most Kantian part of the Critique, we cannot but observe that, where others have advanced the possibility of a priori knowledge through general concepts of the mind, nobody before Kant has come up with the idea of an a priori intuition. In fact, already the paradox nature of such an idea - how indeed could we have an intuition of something, independently of its being there - makes understandable a great deal of the scepticism with which it still has to meet.

But in search for explanations of the controversial reception of Kant's Aesthetic, we cannot suffice with observing the originality of its central idea. Indeed, crucial to the philosophical thesis of the Aesthetic are the expositions of our concepts of space and time, which it contains. Now, in literature, exactly those expositions figure among the most refuted passages of the whole Critique. In what follows, I will limit myself to an interpretation of the metaphysical exposition of space. But as I intend it, the discussion of this interpretation should at the same time provide some support for the thesis that the text of the Aesthetic as a whole makes more sense than is usually assumed. 
The origin of this paper lays in an indication that is to be found in the sixth paragraph of Klaus Reich's book on the completeness of Kant's table of judgments. Reich claims there that, in the metaphysical exposition of the concepts of space and time, Kant has to use the same analytic procedure as the one that guides the unfolding of the moments of thought in judgment in general. This procedure is analytic, because it has to be gone through following the analytic order of the moments of thought, which corresponds to the inverse order of the actual listing of those moments in Kant's table of judgments. Reich shows then very succinctly how, in the four articles of its metaphysical exposition in the second edition of the Critique, the analysis of space is guided by the four possible aspects of object-determination expressed by the four category-titles. ${ }^{1}$ Although it has passed largely unnoticed in Kant-literature, ${ }^{2}$ I think that this clue is of particular interest for any interpretation of the Aesthetic that is not afraid of the ambition, proper to human reason, to be systematic or principle-guided - read: that is not afraid to be properly Kantian.

Several reasons can explain the fact that Reich's indication has not made school in Kant-research. First of all, the passage that I mentioned is only to be found in the first edition of Reich's completeness-book. Second, the English-reading world had to wait for 1992 to see a translation of Reich's important work. ${ }^{3}$ Third, Reich had a typical writing-style, treating of the most complicated matters of interpretation in a short and sketchy way, and thus producing an extremely condensed text, which may be against the common standards of accessibility, even with regard to German readers. But these are all merely contingent factors that of course do not concern Reich's argument and its value as such. It would be unfair, though, not to mention a more immanent problem of Reich's interpretation, which makes that, even if it is noticed and understood, it could be easily dismissed as too subtle. This problem arises when Reich's indication is seen in the light of the text of the first edition of the Critique, where we find not four, but five articles corresponding to the exposition of space. So Reich's indication has the inconvenient property that it somehow implies that it is only at the time of the second edition that Kant would have seen the importance of the table of the categories as a clue for the analysis of our concept of space.

I think that to assume that this is indeed so, is actually not as problematic as one would be inclined to think. Even where it concerns someone of the genius of Kant,

1 See: Reich, Klaus: Die Vollständigkeit der Kantischen Urteilstafel. Berlin: Richard Schoetz, 1932, 61.

2 References to this particular passage in Reich are to be found in Baum, Manfred: „Kants Raumargumente und die Begründung des transzendentalen Idealismus“. In: Kant. Analysen - Probleme - Kritik, Bd. II, ed. by Hariolf Oberer, Würzburg 1996, 41-63, 50 (footnote 6); in: Chenet, François-Xavier, L'assise de l'ontologie critique: l'esthétique transcendantale. Lille 1994, 103-104, and in: Unruh, Patrick: Transzendentale Ästhetik des Raumes. Zu Immanuel Kants Raumkonzeption. Würzburg 2007, 169 (footnote 270). Baum is positive about Reich's clue; Chenet and Unruh reject it.

3 See: Reich, Klaus: The Completeness of Kant's Table of Judgments. Translated by Jane Kneller and Michael Losonsky. Foreword by Lewis White Beck. Stanford, California 1992. 
it shouldn't be too surprising that the author of such a complex and large work as is the Critique would not have noticed from the start all the possibilities of systematic presentation that his own table of necessary a priori concepts of an object in general is offering. Moreover, as the following remarks should make clear, also the text itself is endorsing this hypothesis. 1/The A-edition still does not contain the concept 'exposition'. Thus, where in the B-edition Kant says "let us first expose the concept of space" (B 38), in the A-edition he only says: "let us first consider space" (A 23). 2/Consequently, only the B-edition differentiates between metaphysical and transcendental expositions of space and gives their respective definitions. As the number three of the considerations on space in the A-edition will become what is explicitly referred to as "transcendental exposition of space" in the B-edition, we cannot say that the "considerations" in A present us with some kind of 5-part metaphysical exposition that only wasn't already called so. 3/It is right that the fact that, in the case of time, the B-edition - under the new title "metaphysical exposition of time" - still gives five articles, seems to go against Reich's interpretation. But it should suffice to recall what Kant says about the third article, namely that "in order to be brief", he has "placed that which is properly transcendental under the heading of the metaphysical exposition.” (B 48)

In light of this, it shouldn't be too difficult to admit that Kant, while preparing the second edition of his Critique, has thought that the teaching of the Aesthetic would gain in strength if he introduced the concept of an exposition and ordered anew the "considerations" of the first edition, following now the structural division between a metaphysical and a transcendental exposition. Thus, since a systematic interpretation of the exposition that Kant calls metaphysical has to refer to the Aesthetic of 1787 , it is to the second edition of the Critique that all references will be made. But of course, what follows can also serve to understand those four "considerations" on space in the first edition that will ultimately be taken together under the new heading of metaphysical exposition.

\section{The introduction of the metaphysical exposition of space}

In the opening section of the metaphysical exposition of space, Kant wants us to see that the representations we refer to with the concepts of space and time are far from distinct. He shows that a lot of questions can be asked:

What then are space and time? Are they actual entities? Are they only determinations or also relations of things, though such ones that would also belong to them even if they were not intuited, or are they such ones that only adhere to the form of intuition and thereby to the subjective constitution of our mind, without which these predicates could not be ascribed to anything whatsoever? (B 37-38 $)^{4}$

4 Was sind nun Raum und Zeit? Sind es wirkliche Wesen? Sind es zwar nur Bestimmungen oder auch Verhältnisse der Dinge, aber doch solche, welche ihnen auch an sich zukommen würden, wenn sie auch nicht angeschaut würden, oder sind sie solche, die nur an der Form der Anschauung allein haften und mithin an der subjectiven Beschaffenheit unseres Gemüths, ohne welche diese Prädicate gar keinem Dinge beigelegt werden können? 
Reading the first of these questions, we might expect that the expositions will tell us what space and time are alike. Question two and three then resume four possible answers to this general question about space and time. The second question refers to the way in which Newton thought about space. The third question has three parts, whereby the first and the second parts respectively refer to the explanations of Descartes and Leibniz and the third offers a preview of the answer Kant himself is going to provide. We can thus expect that Kant will show that the answer to the second question and to the first two propositions contained in the third question is "no", leaving his own solution as the only true determination of space. In the next passage, Kant tells us how he is going to arrive at this anticipated result, by considering first the concept of space:

In order to inform ourselves about this, we firstly want to expose the concept of space. Now I understand by exposition (expositio) the distinct (although not complete) presentation of that which belongs to a concept; but the exposition is metaphysical when it contains that which exhibits the concept as given a priori. (B 38$)^{5}$

Here already at least two things should be remarked.

1/Kant indifferently talks about the concept of space. This seems confusing: every year thousands of students learn that, for Kant, space and time are intuitions, not concepts. That is of course true, but it should be noted that talk about "the concept of space" doesn't necessarily imply that space is a concept. The metaphysical exposition will show that space is, originally, an a priori intuition; it will not show that there is no concept of space. If transcendental philosophy has to consider certain intuitions, it can only do so by using concepts that refer to those intuitions. Moreover, I think we can distinguish at least three senses in which one can talk about space as a concept, without opposing thereby the Kantian doctrine that, ultimately, space has an exclusively intuitive origin. Firstly, apart from philosophical analysis, we definitely can still use a concept of space to refer to particular spaces which so to say are falling under the concept (for example in propositions as: "This kind of geometry presupposes a four-dimensional space"; "this car occupies a space which has a volume of $8 \mathrm{~m}^{3}$ "). Thus, each particular form of spatial extension - be it geometrical or empirical - behaves rather unproblematically as an instance of space as a concept. Secondly, we can still talk of the "metaphysical concept" of space, if we understand thereby that it is a concept which, in traditional metaphysics, has always been subject to analysis. Also for Kant, the proper task of the philosopher is to analyse concepts. But, as is illustrated by the incommensurability of the many, equally plausible, positions held by past philosophers, in the case of the concept of space this analysis hasn't been successfully accomplished. Following this interpretation, we can say that the metaphysical exposition offers a new analysis of the traditionally metaphysical concept of space. Thirdly, within the system of transcendental philosophy we can refer to space and

5 Um uns hierüber zu belehren, wollen wir zuerst den Begriff des Raumes erörtern. Ich verstehe aber unter Erörterung (expositio) die deutliche (wenn gleich nicht ausführliche) Vorstellung dessen, was zu einem Begriffe gehört; metaphysisch aber ist die Erörterung, wenn sie dasjenige enthält, was den Begriff als a priori gegeben darstellt. 
time as elementary concepts of sensibility. Indeed, with regard to the transcendental doctrine of elements, we can distinguish between transcendental elements of

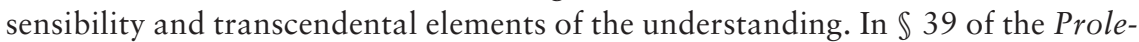
gomena, while he is recalling the enterprise of the first Critique, Kant explicitly calls the transcendental elements of sensibility "elementary concepts of sensibility":

During an examination of the pure (containing nothing empirical) elements of human knowledge, it was only after long reflection that I succeeded in distinguishing and separating with certainty the pure elementary concepts of sensibility (space and time) from those of the understanding. (Prol, AA 04: 323) 6

The citation is unambiguous: Kant conceives of the categories, space and time as the elementary concepts of a priori cognition. Now we know that all cognition has two roots: sensibility and thought. However, doing philosophy, be it transcendental or not, is and will always remain a conceptual activity. Thus it is but consistent to affirm, with regard to the system of transcendental philosophy, that, while the categories are the elementary concepts of pure thought, space and time are the elementary concepts of pure sensibility.

With this in mind, it is not at all necessary to suspect some nonchalance in Kant's writing, and to propose to replace the word 'concept' here with a supposedly better fitting term such as 'general representation' or 'idea'. ${ }^{7}$ When Kant concludes in the transcendental Aesthetic that space is not a concept, this does not at all imply that there is no concept of space. The situation is this: the task of the metaphysical exposition of space is to analyse our given concept of space in order to track its origin, and this analysis will show that the origin of the concept of space is intuitive and not conceptual or logical.

2/When Kant says that the metaphysical exposition of space will have to present what is given a priori with the concept of space, he already seems to assume what he still has to prove: that something in our concept of space is a priori. Notably the first and the second articles of the exposition seem to prove just this priority of space. The first implicitly, by stating that the concept of space is not an empirical concept that has been distilled from outer experiences, and the second explicitly. It may thus not be surprising that midst the controversies in Kant lit-

6 Bei einer Untersuchung der reinen (nichts Empirisches enthaltenden) Elemente der menschlichen Erkenntniß gelang es mir allererst nach langem Nachdenken, die reinen Elementarbegriffe der Sinnlichkeit (Raum und Zeit) von denen des Verstandes mit Zuverlässigkeit zu unterscheiden und abzusondern.

7 As some commentators have done. See for example: Vaihinger, Hans: Commentar $z u$ Kants Kritik der reinen Vernunft, 2 vols., Stuttgart 1892, Vol. II, 155-156; Kemp Smith, Norman, A Commentary to Kant's "Critique of Pure Reason", Second edition, 1923, 99; Paton, Herbert James: Kant's Metaphysic Of Experience, 2 vols., London 1936, vol. I, 108 (footnote 1); Wilkerson, Terence Edward: Kant's 'Critique of Pure Reason'. A commentary for students, Oxford 1976, 22; Allison, Henry: Kant's Transcendental Idealism. An interpretation and Defense (Revised and enlarged edition), New Haven/London 2004, $99 \mathrm{ff}$ (See especially endnote 5 on page $465 \mathrm{f}$ ). The importance of taking Kant's use of the term 'concept' here as serious as its gets has been stressed before by Lorne Falkenstein. See: Falkenstein, Lorne: Kant's Intuitionism: A Commentary on the Transcendental Aesthetic, Toronto 1995, 63-64. 
erature that have arisen from the question about the quality of the 'proofs' that these articles are supposed to contain, one of the most recurrent reproaches is that Kant is begging the question.

First at all though we should remark that to call some philosophical analysis a metaphysical exposition is just a matter of definition. What we know is this: if an exposition presents something that is given a priori, then we call it a metaphysical exposition. At the moment when Kant writes "metaphysical exposition of this concept", he of course already knows that the exposition will trace the concept of space back to something a priori. But this fact doesn't amount to saying that Kant surreptitiously presupposes the apriority of space. (If this was the case, we could accuse the author of a book by saying that the statement made in its title presupposes the conclusion.)

Secondly, if we pay closer attention to what Kant really tells us he is going to do, we remark that he nowhere speaks of proving things. Moreover, not more than he is promising to provide us with proofs is he indicating that something should be proven at all. I take it to be one of the big failures of Kant interpretation, that it has not taken serious enough Kant's definition of an exposition. From his statement about the nature of an exposition, it in no way follows that Kant is going to do more than provide a distinct, though not complete presentation of something that is already given. Moreover - as I argued above - that the exposition will be metaphysical just means that that which Kant is going to present, is given a priori. This a priory nature of space is not deduced, but exposed, which means that it is not subject to proof, but to clarification. ${ }^{8}$ That's why I won't be referring to the four parts of the B-version of the metaphysical exposition as proofs, or, like it is usually done in German Kant literature, as 'arguments'. Nor will I talk about four 'expositions' (plural). I will just assume that there is one metaphysical exposition of space which contains four numbered articles. ${ }^{9}$

8 This is in my opinion the matter of facts from which one has to start to provide an answer to the thorny question concerning the difference between a metaphysical deduction and a metaphysical exposition. The categories have to be introduced by a metaphysical deduction because they can only be given 'mediately' ('mittelbar'). Now, only something which is 'mediately' given can be subject to proof. The metaphysical deduction proves that the categories are the only possible transcendental elements of the understanding and it does so through an analysis of the characteristics of (a conceptualisation of the immediately given) original transcendental apperception. As we know, this deduction is at the same time a proof of the conceptual and a priori nature of the categories. But space and time are immediately given, which means that their introduction as transcendental elements of sensibility doesn't need their deduction from something else. A consequence thereof is that, strictly speaking, one cannot argue anymore against someone who says that space and time are not immediately given, than against someone who says that there is no consciousness. There cannot be a plea in favour of the actuality of the immediately given; philosophical pleas for space and time will therefore only concern particular ways to conceptualise and to understand this actuality.

9 I wish to thank Eva John for her critical comments on a first draft of this article, and more specifically on my interpretation of the concept 'exposition'. 


\section{Kant's conception of a (metaphysical) exposition}

What then exactly is to be understood by exposition [Erörterung]? From the passage preceding the first article, it is clear that an exposition is not the complete presentation of the content of a concept. In the first section of chapter one of the transcendental doctrine of method, we learn that such a complete presentation would be a definition. ${ }^{10}$ But it is impossible to provide a definition of given concepts - be they empirical or a priori. Indeed, giving a definition is only possible for what Kant calls arbitrary concepts, which are not already given before definition, but created by it. This is the case with mathematical concepts, for which the representation can only be said to be given once the construction-procedure contained in their definition has been executed. ${ }^{11}$ That's why mathematics has to start with definitions, whereas philosophy would rather end with them:

[...] philosophical definitions can only be realised as expositions of given [concepts], whereas mathematical [definitions can be realised] as constructions of originally made concepts, the former only analytically through division (the completeness of which is not apodictically certain), the latter synthetically and thus make the concept itself, whereas the first only explicate it. $(\text { B } 758)^{12}$

From this it follows, that philosophy has to pursue another method than mathematics. In philosophy, given concepts are analysed through division. Indeed, because the so-called philosophical definitions are only ...

[...] divisions of given concepts, these concepts, although still unclear, come first, and the incomplete exposition precedes the complete, so that, from some characteristics [Merkmale] that we distilled from a still uncompleted division, we can conclude already a lot, before we have arrived at the complete exposition: that is at the definition; in a word, that in philosophy the definition, as well demarked clearness, must rather conclude than begin the work. (B 758-759) 13

10 Compare Refl 2925: "By declaration a distinct concept is made. [Durch declaration wird ein deutlicher Begrif gemacht.]

By exposition a given concept is made distinct. [Durch exposition wird ein gegebener Begrif deutlich gemacht.]

By definition a distinct concept is made complete and precise. [Durch definition wird ein deutlicher Begrif complet und praecis gemacht.]" (AA 16: 578)

11 As a comparison of the Reflexionen numbers 2947, 2948, 2949, 2950, 2951 (AA 16: 584f.), 2957, 2958, 2959, 2961 (AA 16: 586f.) and 2964 (AA 16: 588) makes clear, Kant seems not to have been sure if a definition of an appearance is possible. Following Refl 2964 , it could be said possible when the appearance in question can be created (Refl 2957: "per fabricationem"), as could be the case with empirical matters such as plaster [Gips], cinnabar [Zinober] or sulphur [Schwefel]. Here we could perhaps arrive at a complete exposition (= a definition) of the empirical object by giving the method for its production.

12 [...] philosophische Definitionen nur als Expositionen gegebener, mathematische aber als Constructionen ursprünglich gemachter Begriffe, jene nur analytisch durch Zergliederung (deren Vollständigkeit nicht apodiktisch gewiß ist), diese synthetisch zu Stande gebracht werden und also den Begriff selbst machen, dagegen die ersteren ihn nur erklären.

13 Denn da sie Zergliederungen gegebener Begriffe sind, so gehen diese Begriffe, obzwar nur noch verworren, voran, und die unvollständige Exposition geht vor der vollständigen, so 


\section{In a footnote to this passage, Kant states further that philosophy ...}

[...] is swarming with faulty definitions, especially such ones that although they contain elements for definition are not yet complete. Now, if one wouldn't know at all what to do with a concept until one would have defined it, then all philosophizing would be in a bad way. But since, [if we go not further than] as far as the elements (of division) reach, we can always make good and certain use of them, even imperfect definitions, that is: propositions that are not already definitions properly, but that nonetheless are true and thus approximations to them, can be used with great advantage. In mathematics the definition belongs $a d$ esse, in philosophy ad melius esse. (B 759) ${ }^{14}$

So, the proper task of an exposition in philosophy is to analyse given concepts. But how can we arrive at an exposition of a concept that is given a priori, such as the concept of space? In Kant's hand exemplar of Meier's Auszug aus der Vernunftlehre, we find some reflections that are of valuable help. I give three of them ${ }^{15}$ :

All making-distinct of a concept is explication. All distinct representation of made concepts is declaration, of given [concepts]: exposition, either empirically or a priori given. That one synthetically, this one analytically. (Refl 2950) ${ }^{16}$

Exposition of that which is given a priori is analytic, of that which is given empirically synthetic. (Refl 2953) ${ }^{17}$

We expose either a concept or the experience. The first is done per analysin, the second per synthesin. Exposing is the ordered representation of the marks that are found per analysin. Although we cannot define, we can nonetheless expose. In case that the exposition is incomplete, we can serve us directe of the concept (from the concept to the properties), but not serve us [of it] as to conclude inverse, i.e. from the properties to the concept. (Refl 2996)18

daß wir aus einigen Merkmalen, die wir aus einer noch unvollendeten Zergliederung gezogen haben, manches vorher schließen können, ehe wir zur vollständigen Exposition, d.i. zur Definition, gelangt sind; mit einem Worte, daß in der Philosophie die Definition, als abgemessene Deutlichkeit, das Werk eher schließen als anfangen müsse.

14 B 759, fn 3: Die Philosophie wimmelt von fehlerhaften Definitionen, vornehmlich solchen, die zwar wirklich Elemente zur Definition, aber noch nicht vollständig enthalten. Würde man nun eher gar nichts mit einem Begriffe anfangen können, als bis man ihn definirt hätte, so würde es gar schlecht mit allem Philosophiren stehen. Da aber, so weit die Elemente (der Zergliederung) reichen, immer ein guter und sicherer Gebrauch davon zu machen ist, so können auch mangelhafte Definitionen, d.i. Sätze, die eigentlich noch nicht Definitionen, aber übrigens wahr und also Annäherungen zu ihnen sind, sehr nützlich gebraucht werden. In der Mathematik gehört die Definition ad esse, in der Philosophie ad melius esse. - Compare with Warschauer Logik, 120-121. (Immanuel Kant. LogikVorlesung. Unveröffentlichte Nachschriften II. Ed. by Tillman Pinder. Hamburg 1998, 614-616 [Kant-Forschungen 9].)

15 Compare with Reflexionen 2920, 2932 and 2937; with $\mathbb{S} 104$ and $\mathbb{} 105$ (note the remarks!) in the Jäsche-Logik, and with Logik Bauch, 94 Anmerkung. (Immanuel Kant. Logik-Vorlesung. Unveröffentlichte Nachschriften I. Ed. by Tillman Pinder. Hamburg 1998, 155 [Kant-Forschungen 8].)

16 AA 16: 585: Alle Deutlich-Machung eines Begrifs ist explicatio. Alle deutliche Vorstellung gemachter Begriffe ist declaratio, gegebener: expositio, entweder empirisch oder a priori gegebener. Jene synthetisch, diese analytisch.

17 AA 16: 585: exposition ist in a priori gegebenen analytisch, in empirisch gegebenen synthetisch.

18 AA 16: 608: Wir exponiren entweder einen Begrif oder die Erfahrung. Das erste geschieht per analysin, das zweyte per synthesin. Das exponiren ist die [klare Vorst] an einander 
From this it should be clear that the exposition of an a priori given concept has to present its characteristics by analysis. But what is it that we can analyse in the case of the concept of space? Each concept has an intension, which means that we can assume that, by using the concept of space, we refer to some content of the concept, to "a something" that is given to us. How exactly this content is given is not clear at first sight and the task of the exposition will be to further determine what space is like. Indeed, the fact that Descartes, Leibniz and Newton each had a different answer to the question about space, shows that it does not reveal its true nature in a self-evident way. To assume such initially confused understanding of space does not of course imply that the spatiality of our appearances would be merely a confused way to represent essentially space-less intelligible entities, like Leibniz would have it. For Kant, it only implies that it is necessary to further analyse and determine the content of that which we refer to with the concept of space. And it is clear that to determine some content, this content first has to be given.

\section{The a priori content of our given concept of space}

Kant will show, by analysing the given discursive or so-called "general" concept of space, that space has its origin in an a priori intuition which precedes all particular, determinate spaces to which the discursive concept 'space' applies. When Kant wants to refer to space as this undetermined a priori intuitive origin of every determinate space, he will use the formula "form of intuition". It is space so considered that Kant refers to when he speaks of it as an elementary concept of sensibility.

Now, only determined intuitions can be given to us in a conscious manner. As a consequence, the only content of the concept of space that can be actually given is the representation of space as a formal intuition. Thus, a major difficulty for the interpretation of the metaphysical exposition is the fact that it can only analyse the intension of the discursive concept of space - the concept which applies to a whole range of particular, determinate spaces -, while it will at the same time show that this concept presupposes that space has an a priori and conceptually undetermined intuitive origin. In other words: through the analysis of the (determined) representation of space as a formal intuition, the metaphysical exposition will show that this representation is secondary to space considered as an original (undetermined) intuitive manifold. How can the metaphysical exposition pursue such a program?

Since the content of the concept of space is not clear from itself (see the confusion among philosophers), the metaphysical exposition cannot assume more than that space must be a "something" ["ein Etwas"]. But even this minimal assumption amounts to considering space as a given object, and, as the transcenden-

hangende Vorstellung der Merkmale, die per analysin gefunden sind. Wenn wir gleich nicht definiren können, so könen wir doch exponiren. In dem Fall, daß die exposition incomplet ist, können wir uns des Begrifs directe bedienen (von dem Begrif auf die Eigenschaften), aber nicht inverse zu schließen bedienen, d.i. von den Eigenschaften auf den Begrif. 
tal Analytic will teach, this is possible only when we consider space as given in an intuition. Thus space, considered as a given object, has to be the representation of some manifold. Kant allows us to be more specific on that manifold, when we look how he refers to the transcendental Aesthetic later on in the Critique. In that aspect, the following passage from $\mathbb{S} 26$ of the transcendental deduction of the categories is important:

Space and time are not merely represented a priori as forms of sensible intuition, but as intuitions themselves (which contain a manifold), that is: with the determination of the unity of that manifold in them (see transsc. aesthet.) (B 160)19

But already $\mathbb{} 10$ of the Analytic contained important clues. It is said there that the Transcendental Aesthetic provides the Transcendental Logic with a manifold a priori, contained in space and time. And that, although space and time are independent a priori conditions of our receptivity, the spontaneity of human thought "requires that this manifold first be gone through, taken up, and combined in a certain way in order to make a cognition out of it. I call this action synthesis." (B 102)20 A little further, Kant is very clear about the fact that the representation which results from such a synthesis - even if this synthesis is one that comprehends an a priori given content - does not provide us automatically with a clear cognition:

The synthesis of a manifold (whether it be given empirically or a priori) first brings forth a cognition, which to be sure may initially still be raw and confused, and thus in need of analysis; yet the synthesis alone is that which properly collects the elements for cognitions and unifies them into a certain content [...]. (B $103-$ my italics $)^{21}$

It is at this point that we should once more take serious one of the fundamental teachings of the Critique, namely the famous thesis that mere intuitions are blind. One the one hand, it is rather obvious that, if we want to analyse a concept, some content or matter of the concept (its intension) should be given prior to that analysis. We saw further that, for Kant, the only possible content to which the concept of space can be supposed to refer is the manifold represented in the intuition of space. But, on the other hand, since also that intuition of space would be blind without concept, the concept of space, if it has to represent at all, cannot be treated as referring to something totally independent from the synthesis that makes this concept possible. In other words: that what we represent when we use the concept space as to refer to the intuition of space as a given manifold, is not some sort of original spatial dispersion but contains the unity of the manifold

19 Aber Raum und Zeit sind nicht bloß als Formen der sinnlichen Anschauung, sondern als Anschauungen selbst (die ein Mannigfaltiges enthalten), also mit der Bestimmung der Einheit dieses Mannigfaltigen in ihnen a priori vorgestellt (siehe transsc. Ästhet.).

20 Allein die Spontaneität unseres Denkens erfordert es, daß dieses Mannigfaltige zuerst auf gewisse Weise durchgegangen, aufgenommen und verbunden werde, um daraus eine Erkenntniß zu machen. Diese Handlung nenne ich Synthesis.

21 Die Synthesis eines Mannigfaltigen aber (es sei empirisch oder a priori gegeben) bringt zuerst eine Erkenntniß hervor, die zwar anfänglich noch roh und verworren sein kann und also der Analysis bedarf; allein die Synthesis ist doch dasjenige, was eigentlich die Elemente zu Erkenntnissen sammlet und zu einem gewissen Inhalte vereinigt [...] 
which is provided by the synthesis that is needed to bring the manifold under a concept. In the footnote to the cited passage, Kant is teaching us about just this complication of the matter.

Space, represented as object [Gegenstand] (like one really needs it in geometry), contains more than mere form of intuition, namely comprehension [Zusammenfassung] of the manifold given in accordance with the form of sensibility in an intuitive representation, such that the form of intuition merely contains a manifold, whereas the formal intuition gives unity of the representation. In the Aesthetic I had ascribed this unity merely to sensibility, just to remark, that it precedes all concept, although to be sure it presupposes a synthesis which does not belong to the senses but through which all concepts of space and time first become possible. For since through it (as the understanding determines sensibility) space or time are first given as intuitions, the unity of this intuition a priori belongs to space and time and not to the concept of the understanding [...]. (Fn1, B 160)22

From this, it is clear that where space is considered as an intuition, it requires the same things as every other intuition: a given manifold, a synthesis and a reduction to the unity in consciousness. In the cited note, Kant also acknowledges that the Aesthetic didn't deal with the part of the understanding in the realisation of space as an intuition. Indeed, in the Aesthetic, nowhere the difference between form of our intuitions and formal intuition is really made explicit. ${ }^{23}$ There is a

22 Der Raum, als Gegenstand vorgestellt (wie man es wirklich in der Geometrie bedarf), enthält mehr als bloße Form der Anschauung, nämlich Zusammenfassung des mannigfaltigen nach der Form der Sinnlichkeit Gegebenen in eine anschauliche Vorstellung, so daß die Form der Anschauung bloß Mannigfaltiges, die formale Anschauung aber Einheit der Vorstellung giebt. Diese Einheit hatte ich in der Ästhetik bloß zur Sinnlichkeit gezählt, um nur zu bemerken, daß sie vor allem Begriffe vorhergehe, ob sie zwar eine Synthesis, die nicht den Sinnen angehört, durch welche aber alle Begriffe von Raum und Zeit zuerst möglich werden, voraussetzt. Denn da durch sie (indem der Verstand die Sinnlichkeit bestimmt) der Raum oder die Zeit als Anschauungen zuerst gegeben werden, so gehört die Einheit dieser Anschauung a priori zum Raume und der Zeit und nicht zum Begriffe des Verstandes $[\ldots]$.

23 See for example the first $\mathbb{S}$ of the Aesthetic: “[...] the pure form of sensible intuitions in general is to be encountered in the mind a priori, wherein all of the manifold of appearances is intuited in certain relations. This pure form of sensibility itself is also called pure intuition. [Demnach wird die reine Form sinnlicher Anschauungen überhaupt im Gemüthe a priori angetroffen werden, worin alles Mannigfaltige der Erscheinungen in gewissen Verhältnissen angeschauet wird. Diese reine Form der Sinnlichkeit wird auch selber reine Anschauung heißen.]" (B 34-35), and the following two passages from "Conclusions from the above concepts": "[...] it can be understood how the form of all appearances can be given in the mind prior to all actual perceptions, thus a priori, and how as a pure intuition, in which all objects must be determined, it can contain principles of their relations prior to all experience. [[...] so läßt sich verstehen, wie die Form aller Erscheinungen vor allen wirklichen Wahrnehmungen, mithin a priori im Gemüthe gegeben sein könne, und wie sie als eine reine Anschauung, in der alle Gegenstände bestimmt werden müssen, Principien der Verhältnisse derselben vor aller Erfahrung enthalten könne.]" (B 42); "The constant form of this receptivity [...] is a necessary condition of all the relations within which objects can be intuited as outside us, and, if one abstracts from these objects, it is a pure intuition, which bears the name of space. [Die beständige Form dieser Receptivität [...] ist eine nothwendige Bedingung aller Verhältnisse, darin Gegenstände als außer uns angeschauet werden, und wenn man von diesen Gegenständen abstrahirt, eine reine Anschauung, welche den Namen Raum führt.]” (B 43) 
rather simple reason for that, which has to do with the inherent constraints of the presentation of a new philosophical system.

Because in the actual order of presentation of the Critique it is treated before the Analytic, the Aesthetic cannot already incorporate all teachings that will follow. That's why, in the Aesthetic, Kant still has to introduce the idealism of space and time from within some vaguely assumed classical theory of representation, where our concepts would ideally stand in a one-to-one ontological correlation with their referees. It is clear for example that the operation of isolation and extraction that Kant describes in $\mathbb{S} 1$ of the Aesthetic in order to come to pure intuition $^{24}$ is highly problematic if we bear in mind what the Analytic will teach concerning the inevitable contribution of (human) understanding to (human) knowledge. Even if we conceive of this procedure of isolation as some kind of thought experiment, which merely tries to know what would be the result if we could think away all of our understanding and all empirical content from our representations of outer sense, in the light of the Analytic, we have to conclude that the result of such a hypothetical operation of extraction could never be represented and we certainly wouldn't be able to refer to it as knowledge. It would be something of which we never could be aware as such, because of the absence of any unification of that something through the synthetic act of the understanding, which alone could make it a content of which we are conscious.

It should be clear that this kind of space, as a pure form and pure manifold of which we can never be aware as such, is not what is needed and used in geometry. The geometer needs at least some positively determined representation of space, be it infinite space (Euclidean or not) or some kind of fragmentary space, to be able to do his work. So space as a pure but unrepresentable formal diversity is definitely not going to do the job. Now, that the geometer needs and uses a positively determined concept of space means nothing else than that he needs and uses the representation of space as (some kind of) object. ${ }^{25}$

\section{Space as form and space as matter}

Following Kant, three elements condition the representation of (every kind of) object: diversity; the synthesis of this diversity; and unity. In the case of the formal intuition of space, i.e. space considered as an object, these three conditions can be specified as follows: 1 . the manifold a priori, i.e. space as pure form, as delivered

24 See B 36: „In the transcendental aesthetic, we will [...] first isolate sensibility by separating off everything that the understanding thinks through its concepts, so that nothing but empirical intuition remains. Second, we will then detach from the latter everything that belongs to sensation, so that nothing remains except pure intuition and the mere form of appearances [...]. [In der transscendentalen Ästhetik [...] werden wir zuerst die Sinnlichkeit isoliren, dadurch daß wir alles absondern, was der Verstand durch seine Begriffe dabei denkt, damit nichts als empirische Anschauung übrig bleibe. Zweitens werden wir von dieser noch alles, was zur Empfindung gehört, abtrennen, damit nichts als reine Anschauung und die bloße Form der Erscheinungen übrig bleibe [...].]” (my italics).

25 Some kind of object: ens imaginarium (See B 348). 
by the transcendental Aesthetic, 2. a figurative, productive synthesis of that manifold, and 3. the unity provided by the categories. So it is really the understanding which, through the synthetic unification of formal sensibility (in casu the pure manifold of space as form of outer intuition), will bring forth the intuitive representation of space as an object. In the transcendental deduction, Kant will show that this intuitive unity of space is one of the conditions to which empirical data have to conform in order to be cognizable, since it is the representation of the form of their reception in the subject.

To be able to follow this line of thought, it is important to understand that the form-matter distinction is not one that can determine a thing without this thing being put in relation with some other thing. In other words: a representation considered in itself is neither form nor matter. As Kant teaches in the appendix concerning the amphiboly of the concepts of reflection, it is only in considering the relation between representations that we can say of one representation that it is form and of another that it is matter. But Kant also clearly states there that it is proper to human understanding to consider matter as preceding form, because to speak of the form of something supposes this something already be given as a matter that consecutively can be determined by the form. "The understanding [...] first demands that something is given (at least in the concept) to be able to determine it in a certain way. Hence in the concept of pure understanding matter precedes form [...]" (B 322-323) ${ }^{26}$ As Kant further explains, that is also why it is so difficult for the understanding to accept that there might be a form that precedes matter. Indeed, one of the central concerns of human understanding - to be firstly in possession of a matter that can be consecutively determined by a form - is not satisfied when space is a form that precedes matter, and that's why human understanding will be inclined to thinking the thing in itself as something which is more than an ens rationis (empty concept without object), for example as a cause or as a something that affects sensibility. Hence the difficulty for the understanding to accept as it stands there the central thesis of the transcendental Aesthetic, that space and time precede the matter of appearance. Indeed, when we have to do with "sensible intuitions, in which we determine all objects only as appearances, then the form of intuition (as a subjective constitution of sensibility) precedes all matter (the sensations), and thus space and time precede all appearances and all datis of experience and make these possible in the first time." (B 323)27

If we now look at how the form-matter distinction applies to the transcendental reasoning concerning space, we see that what is first described as the form of outer intuition becomes itself the matter of the representation (or the pure intuition) of space. The initial pure form thus receives another form, namely that of

26 Der Verstand [...] verlangt zuerst, daß etwas gegeben sei (wenigstens im Begriffe), um es auf gewisse Art bestimmen zu können. Daher geht im Begriffe des reinen Verstandes die Materie der Form vor [...].

27 [...] sinnliche Anschauungen, in denen wir alle Gegenstände lediglich als Erscheinungen bestimmen, so geht die Form der Anschauung (als eine subjective Beschaffenheit der Sinnlichkeit) vor aller Materie (den Empfindungen), mithin Raum und Zeit vor allen Erscheinungen und allen datis der Erfahrung vorher und macht diese vielmehr allererst möglich. 
synthetic unity. This latter unity cannot be provided by the manifold itself, nor by pure sensibility. In other words: synthetic unity cannot be present in what we have when we consider - in transcendental reflection - space as pure form as matter of a representation. If we ask now where this synthetic unity comes from, we cannot but conclude that we have to seek its origin in what transcends mere receptivity. Transcendental reflection - i.e. the reflection that determines the transcendental topoi of our representations - will reveal that this unity must have its origin in the relation between our mere receptivity and the active and determining consciousness of apperception. Indeed, in the transcendental deduction it is shown that this relation necessarily brings forth the unity of the representation, because all manifold a priori is grasped together in an identical act of synthesis and brought to the unity of one same consciousness.

\section{The a priori categorical determination of our concept of space}

When the intuition of space is considered of as some kind of object - which is what the geometer needs, and also what Kant needs to be able to expose space as something given -, this is only possible if that intuition has been brought under the unity-functions that are the categories. So, if the program of the exposition is to clarify the a priori given concept of space, then we should seek by way of transcendental reflection in which manner the content under our concept of space is determined by the categories. This means, that in order to expose our given representation of space, we should analyse this representation to see how it is determined in regard of modality, relation, quality and quantity. The analysis will thus contain four parts, which is exactly what the B-exposition is presenting us with. ${ }^{28}$ But for this explication of the metaphysical exposition to be entirely convincing, we should be able to provide an answer to two further problems. The first problem is arising when we concentrate on the first two articles of the B-exposition. Indeed, while one can easily see that the third and fourth article provide the analysis of our representation of space with regard to its determination under the aspect of, respectively, quality and quantity, it seems not at all to be clear that the first and the second article provide us with the analysis of this representation in relation to determinations concerning, respectively, modality and relation. If we would have to link these two first articles with a category-title of our choice, then it would seem more natural to link the second - the only one speaking of the necessity of our representation of space - with modality, and the first with relation. This brings us to the second, more general problem: Why should the

28 As Reich remarks in an annotation in his hand exemplar, this clue of his seems to have been used without indication of source by Herman Jean De Vleeschauwer in his monumental work on the transcendental deduction. See: Vleeschauwer, Herman Jean De: La Déduction transcendantale dans l'ouvre de Kant, tome III, Antwerpen, 1937, 247. (The annotation concerning De Vleeschauwer is rendered in the edition of the complete works of Reich: Klaus Reich. Gesammelte Schriften. Mit Einleitung und Annotationen aus dem Nachlaß. Ed. by Manfred Baum et al. Hamburg 2001, 472.) 
exposition of space follow a fixed order while analysing the particular categorical determinations of our representation of space? And, more precisely, why should the exposition start with modality and end with quantity, thereby reversing the order in which Kant has actually written down the table of the categories?

Let's start with the second question, and see if it can have any sense to say that the exposition not only does, but has to follow the inverse order of the table of categories. First of all, we should know if Kant himself says something about such an inverse order. The answer is: yes, he does, in a passage from the B-version of the paralogisms of pure reason. During the refutation of Mendelssohn's proof of the persistence of the soul, he contrasts a synthetic connection of the topics of rational psychology ("[...] if from the category of relation [...] we go backward [...]") with the possibility to follow an analytic procedure, where "[...] the propositions of the rational doctrine of the soul begin not from the concept of a thinking being in general but from an actuality" [so würden die Sätze der rationalen Seelenlehre nicht vom Begriffe eines denkenden Wesens überhaupt, sondern von einer Wirklichkeit anfangen]. (B 418) This analytic procedure is ...

[...] grounded on the "I think" given as a proposition that already includes existence in itself, and hence grounded on modality. (Ibid.) ${ }^{29}$

In an analogous way, when Kant says that in the metaphysical exposition he will analyse the given concept of space, we should understand this as a statement of the fact that the analysis is laying at its base the actuality of our representation of space. This actuality means nothing else than the actual fact that we are in possession of a representation of space, and that thus a representation of space as some kind of object exists at a determinate time. ${ }^{30}$ If we try to have a broader view on this matter, we can state that every introduction of transcendental elements (elementary concepts of a priori knowledge), in order to come to a distinct consciousness of these elements, will have to be accompanied by a thoroughgoing analysis of what is given with the elementary concept. Such an analysis will al-

29 [...] Ich denke, als ein Satz, der schon ein Dasein in sich schließt, als gegeben, mithin die Modalität zum Grunde liegt [...]. - This is so because, as a principle, thoroughgoing determination is grounded on the objective unity of consciousness, which in itself is already an existence determined in space and time. That's also why the moments of the function of our thought in judgments (i.e. the table of judgments) not only should, but can be derived by a metaphysical deduction that is grounded on the objective unity of apperception as the (given) mere form of human thought. (For such an account of the metaphysical deduction, see: Reich, Klaus, Op. cit.).

30 That space is indeed represented as an actual object, is stated in passing when Kant is making an analogy between space and the transcendental ideal at B 647: „For, just as with space, since it originally makes possible all forms which are merely limitations of it, even though it is only a principle of sensibility, it is necessarily held to be a Something subsisting in itself with absolute necessity and an a priori object given in itself, so [...]" (my italics). [Denn so wie der Raum, weil er alle Gestalten, die lediglich verschiedene Einschränkungen desselben sind, ursprünglich möglich macht, ob er gleich nur ein Principium der Sinnlichkeit ist, dennoch eben darum für ein schlechterdings nothwendiges für sich bestehendes Etwas und einen a priori an sich selbst gegebenen Gegenstand gehalten wird: so $[\ldots]$. 
ways have to start with a reflection on the modality of this givenness, because it has to start from the given actuality of this element in general -i.e. from its existence at a determinate time, which is already a modal determination - and the way in which the element as actuality is related to our faculty of knowledge. If this is right, we just provided the answer to our second question: because space is an elementary transcendental concept, its metaphysical exposition has to start with the analysis of how the representation of space is determined with regard to modality. But then we still have to answer the first question. Is there a way to provide evidence for our solution of the second problem by showing that this is indeed what Kant is doing in the first article of the exposition: to analyse the elementary concept of space by looking to the way in which it is determined with regard to modality?

Let's turn once again to the amphiboly-appendix. There we learn that the transcendental reflection about something from the point of view of modality will analyse that something with regard to its form and its matter. As evidence for the solution to the second problem, Kant also states there that these two concepts "ground all other reflection", because they are inseparably "bound up with every

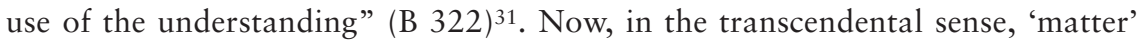
signifies 'the determinable in general', whereas 'form' signifies 'determination'. (ibid.) But how can the analysis of something with regard to modality (starting from the actuality of this something, i.e. from its modal categorical determination as 'existence') provide us at the same time with $1 /$ the determination of this something in regard to our faculty of knowledge; and 2/the determination of this something as form or as matter? The answer is that determining the modality of givenness of a thing just consists in determining the relation of this something to our faculty of knowledge, and that this in turn amounts to determining if, with regard to our faculty of knowledge, this something is considered as form or as matter. Let's see now if we can make any sense of the preceding by going back to the first article of the exposition.

\section{The first article of the metaphysical exposition}

I) Space is not an empirical concept that has been drawn from outer experiences. For in order for certain sensations to be related to something outside me (i.e., to something in another place in space from that in which I find myself), and also in order for me to be able to represent them as outside and next to one another, so, not merely as different but as in different places, the representation of space must already lie as a ground. Consequently the representation of space cannot be obtained from the relations of outer appearance through experience, but this outer experience is itself first possible only through this representation. $(\text { B } 38)^{32}$

31 Dieses sind zwei Begriffe, welche aller andern Reflexion zum Grunde gelegt werden, so sehr sind sie mit jedem Gebrauch des Verstandes unzertrennlich verbunden.

32 1) Der Raum ist kein empirischer Begriff, der von äußeren Erfahrungen abgezogen worden. Denn damit gewisse Empfindungen auf etwas außer mir bezogen werden (d.i. auf 
Once we know that Kant should provide us here with the analysis of the relation of the representation of space to our faculty of knowledge, it is not difficult to see that this is indeed what happens. Thus, when Kant speaks about the representation of space as the condition (the ground) of our ability to represent certain sensations as being related to something that is spatially located outside me, it is clear that he determines space as a condition of the possibility of outer experience. The analysis of the representation of space with regard to modality, i.e. with regard to its relation to the faculty of knowledge, determines this representation of space as a condition of the possibility of empirical knowledge of outer objects. For us, to be able to be in possession of empirical knowledge of outer objects, i.e. to have outer experience, means to be able to relate certain sensations to something located outside us, and this ability presupposes the representation of space. Moreover, we can see that this determination of the relation between our faculty of knowledge and the representation of space is provided by determining if, with regard to outer experience, space is form or matter. Indeed, whereas the 'certain sensations' of which Kant is speaking have to be considered as the 'matter' of empirical knowledge about outer objects (i.e. outer experience), spatiality (i.e. the order between different places) has to be considered as its 'form'.

I think that this is really all that Kant wants to do in the first article. He is starting from the actuality of the representation of space, whereby this representation is already categorically determined as existence at a determinate time (namely the time during which we are representing the representation of space). But if we want to analyse the categorical determination of the representation of space with regard to modality, such a categorical determination will only be valid if it can be seen as a time determination of an intuition. That's why the metaphysical exposition needs the representation of space as some kind of object [Gegenstand], namely as ens imaginarium or formal intuition, and not merely as the as such unrepresentable form of intuition. From the actuality of the representation (existence), 33 the analysis with regard to modality "goes up" to determine space in view of the category pair 'necessity - contingency'. In determining space as a necessary condition for outer experience, space is determined at the same time as a necessary form of the matter (sensations) of outer experience.

That it is in relation to outer experience that our representation of space is determined as a necessary representation is confirmed by a particular passage of Kant's remarks on a letter of Daniel Friedrich von Lossow dating from the $28^{\text {th }}$ of

etwas in einem andern Orte des Raumes, als darin ich mich befinde), imgleichen damit ich sie als außer und neben einander, mithin nicht bloß verschieden, sondern als in verschiedenen Orten vorstellen könne, dazu muß die Vorstellung des Raumes schon zum Grunde liegen. Demnach kann die Vorstellung des Raumes nicht aus den Verhältnissen der äußern Erscheinung durch Erfahrung erborgt sein, sondern diese äußere Erfahrung ist selbst nur durch gedachte Vorstellung allererst möglich.

33 Of course, since the exposition already presupposes the actuality of our representation of space (our "a priori given concept of space"), a determination in view of the category pair possibility-impossibility doesn't have to be undertaken, the actuality of the representation automatically including its possibility. 
april 1774, which provide important materials in view of the future expositions of space and time. ${ }^{34}$ There Kant notes:

It [space] is necessary, because it is the first condition of the possibility of outer representations; hence it is the ground of the ability of outer representations, and we cannot represent us the contrary, because then we would need a still higher ability. (AA 17: 638) ${ }^{35}$

And a bit further, Kant states that

[... Space] is the condition not of things, but of the phenomenon of things, and more precisely of outer sense. (AA 17: 641) 36 $^{36}$

But even if this passage confirms our interpretation of the first article of the exposition, it takes us no further in explaining why it is only in the second article that Kant speaks of the necessity of the representation of space. Assuming that it is true that the first article is exposing space with respect to the modality of its givenness as formal intuition, is there any evidence to conclude that the second article is exposing the determination of space with regard to the category of relation?

\section{The second article of the metaphysical exposition}

2) Space is a necessary representation, a priori, that is the ground of all outer intuitions. One can never make a representation of it, that there is no space, ${ }^{37}$ though one can very well think that no objects are to be encountered in it. It is therefore regarded as the condition of the possibility of appearances, not as a determination dependent on them, and is an a priori representation that necessarily grounds outer appearances. (B 38-39) $)^{38}$

The only manner to come away with the problem that only the second article explicitly mentions the necessity of the representation of space seems to lay in an interpretation that holds it that the first and the last sentence are merely restating what was already the conclusion of the first article. But what, in that case, can be the supplementary task of the second article of the exposition? Although in our interpretation it can start from the already modally determined representation of

34 These remarks have been reproduced by Adickes in the first volume of the reflections on metaphysics, just before the Duisburg-Nachlaß, as Refl 4673 (see AA 17: 636-642).

35 Er [der Raum] ist nothwendig, weil er die erste Bedingung der Moglichkeit der außeren Vorstellungen ist; folglich ist er der grund der Fahigkeit außerer Vorstellungen, und wir können uns das Gegentheil nicht vorstellen, weil wir sonst noch eine [ander] hohere Fahigkeit haben müsten.

36 Er ist die Bedingung nicht der Dinge, sondern des Phänomenon [der] von [einem] den Dingen, und zwar [wer in Ansehung der durch den außeren Sinn] von dem außeren Sinn.

37 This should be read as: "One can never represent that there would be no space [...]".

38 2) Der Raum ist eine nothwendige Vorstellung a priori, die allen äußeren Anschauungen zum Grunde liegt. Man kann sich niemals eine Vorstellung davon machen, daß kein Raum sei, ob man sich gleich ganz wohl denken kann, daß keine Gegenstände darin angetroffen werden. Er wird also als die Bedingung der Möglichkeit der Erscheinungen und nicht als eine von ihnen abhängende Bestimmung angesehen und ist eine Vorstellung a priori, die nothwendiger Weise äußeren Erscheinungen zum Grunde liegt. 
space (as the result of number 1), number 2 would then still have to determine the role that space plays in its relation, not to our faculty of knowledge, but to other things. The second article thus should analyse whether space, in its relation to other things, has to be determined as substance or as accident. Now when Kant says that "one can never represent that there is no space, though one can very well think that there are no objects to be encountered in it", he determines space as something that stays during time, namely as the substratum of all objects. This means that the representation of space is categorically determined by the category of substance, because this category, considered as time determination (scheme), is the "[...] persistence of the real in time, i.e., the representation of the real as a substratum of empirical time-determination in general, which therefore endures while everything else changes." (B 183) (39 $^{39}$ The second article of the exposition indeed states that space is that which always is still there, not only during the changing presence of objects (their appearing and disappearing), but even if all objects would disappear.

In other words, what the second article of the exposition is showing us, is, that, because it is possible for us to have an intuition of the form of all intuition (namely the representation of space as some kind of object), we have to conceive of space as the substratum of all objects. It is the fact that we can understand without problems the abstraction procedure that Kant describes at the beginning of the Aesthetic, thus the fact that we are able to conceive a space without objects (i.e. independently of empirical intuition), that determines our representation of space as the (a priori) substratum of those objects. Inversely, because we cannot represent objects without representing them as spatially extended, in the relation between 'space' as an object and 'these objects' as other objects, the latter will be determined as accidents. When it is repeated then in the second article that space is "regarded as the condition of the possibility of appearances", we can now interpret this slightly otherwise, namely as stating that, within our given representation of space, we regard space as (some kind of) substance that is the condition of the possibility of the appearances (plural = objects) as (some kind of) predicates inhering in it. And when it is said that the representation of space is not "a determination dependent on them [appearances]", this also has to be interpreted as stating that space is not an accident of appearances. Or, to use the 'German' terminology of the table of categories, space is subsistence, and the objects of outer intuition (appearances) "inhere" in that space.

This is not to say that space is a physical substance, but merely that, when our representation of space is analysed in view of its relation to outer appearances, we have to conceive of space as substratum of the appearances, that is: as if it is substance in relation to the objects as accidents. Thus, in an annotation to $\mathbb{S} 233$ of Baumgarten's Metaphysica, Kant remarks:

39 Das Schema der Substanz ist die Beharrlichkeit des Realen in der Zeit, d.i. die Vorstellung desselben als eines Substratum der empirischen Zeitbestimmung überhaupt, welches also bleibt, indem alles andre wechselt. 
A phaenomenon that is a substratum of other phaenomenis is not therefore substance, or only comparative. In the appearances we cannot recognize something as substance (this is only a concept of the apperception), but something only appears as the substratum of the appearance, to which all in the appearance is joined. (Refl 5312) ${ }^{40}$

Seen from within the transcendental Analytic, it is of course an analytically following consequence that a necessary condition of outer experience is also a necessary condition of the objects of outer experience. That is, I think, the reason why the first two articles can easily seem to be interdependent and to contain certain redundancies. But from within the analysis of our representation of space, that is: from the point of view of the transcendental Aesthetic, it is still something different to say, one the one hand, that this representation is a necessary condition of outer experience, and, on the other hand, that it is the (necessary) substratum of all objects of outer appearance. A closer examination indeed has to distinguish between "outer experience" (singular) in the first article and "outer appearances" or "outer intuitions" (plural) in the second article.

\section{The third and fourth articles of the exposition}

That the third and fourth article of the metaphysical exposition of space are concerned with the analysis of our representation of space with regard to, respectively, quality- and quantity-determination, is more easily seen. So, if I will be shorter on these articles of the exposition, this is certainly not because I believe that they ask for less interpretation, but because their text is more directly supporting what I am defending here, namely that the metaphysical expositions inside the Aesthetic are to be interpreted as an analysis of our representations of space and time in view of their categorical determination.

The third article determines our representation of space qualitatively as absolutely homogenous ("is essentially single, and the manifold in it [...] rests merely on limitations" - B 39). So, what falls under our representation of space is always secondary to this representation itself. That is: every particular space is so to say a portion taken out of space as one. Every portion of space can only be represented when thought as residing in the one, global, continuous and absolutely homogenous space, and the former, particular space, cannot thus be prior to the latter, absolute space. ${ }^{41}$ Therefore our concept of space, as we represent it, is a

40 AA 18: 150: Ein phaenomenon, was ein substratum ist von andern phaenomenis, ist darum nicht substantz als nur comparative. In den Erscheinungen können wir nicht etwas als substantz erkennen (dieses ist nur ein Begrif der apperception), sondern etwas erscheint nur als das substratum der Erscheinung, dem alles in der Erscheinung beygelegt wird.

41 In my opinion, since Kant thus conceives of space as totum non-compositum, it is not false to link transcendental idealism with the conception of space as absolute. One should only keep in mind that for the Critical philosophy, absolute space is not transcendentally real. And that is what makes Kant's conception of space different from Newton's. In 1768 and here I disagree with Klaus Reich (see his introduction in Kant, Immanuel: Träume eines Geistersehers. Der Unterschied der Gegenden im Raume. Hamburg 1975, X-XII) who does not seem to distinguish sharply enough between a (metaphysical) proof of the 
concept of what is originally an intuition, and not a discursive concept (where the representation of the instances falling under the concept precedes the concept itself).

In the fourth article, our representation of space is quantitatively determined as an infinite given magnitude. As in the preceding numbers, it is important to stress the fact that we are concerned here with space as it is given in our representation. Now, actual infinity of space is only possible within a subjectively given a priori representation of space. Indeed, as objectively given a priori, space is always finite, because every objective a priori space is the result of geometrical construction. And although we may be able to represent the possibility of infinite space through an objectively given space (for example when we conceive of the possibility to make a line always longer than it actually is), we thereby never represent actual infinity.

But, as Kant has seen, this actual infinity of our representation is not compatible with the thesis that this representation would be a discursive concept. Being but a partial representation, a discursive concept can contain a possible infinity of representations falling under it (as the sphere of the concept), but it cannot contain an actual infinity in itself (as the content of the concept). In other words: it is only because of the fact that the content of any discursive concept is finite (partial) that it can apply to a sphere of representations falling under it. Thus we can say in general that, when a representation contains actual infinity, this implies automatically the infinite particularity of (the content of) that representation. But then it would be senseless to keep on speaking of a sphere of (representations falling under) that representation, because as infinitely particular, such a representation can never be contained in other representations. So we can conclude from the actual infinity of our given representation of space that it must be originally an intuition and not a discursive concept.

Of course a detailed analysis and explanation of these last two articles would require a more lengthy development, but as support to the central thesis of this paper the above should suffice. Moreover, a short passage from the seventh fascicle of the Opus postumum happily confirms the possibility of a categorical determination of the representation of space, especially with regard to these two last numbers of the B-exposition:

Space is not something existing outside my representation: not more than time is; nonetheless [it is] something given a priori that can also be brought under categories for example [number 3 of the exposition - quality:] the unity thereof (there is one space and time) [number 4 of the exposition - quantity:] As a magnitude that, as totality, has always to be thought as but the part of a given still bigger totality, hence as infinite. (AA 22: 22) ${ }^{42}$

absoluteness of space and a (transcendental) proof of the imperceptibility of empty space Kant accepts and proves the absoluteness of space. But from 1770 on, this absoluteness of space is coupled with its transcendental ideality, implying that it cannot be considered as a thing in itself (as Newton presumably did). Compare with AA 18: 151, Refl 5316.

42 Der Raum ist nicht etwas Existirendes ausser meiner Vorstellung: eben so wenig auch die Zeit; dennoch aber etwas a priori gegebenes was auch unter Categorien gebracht werden kann z.B. der Einheit derselben (es ist Ein Raum u. Zeit) Als eine Größe die als Ganzes immer nur wie Theil eines gegebenen noch großeren Ganzen mithin als unendlich gedacht werden muß. 


\section{The tautology objection against the first article of the metaphysical exposition}

In the above, I used the clue that is provided by the category-titles in their analytical order to interpret each article of the metaphysical exposition of space. I hope to have shown that, when this clue is seen in the perspective of, on the one hand, what Kant understands when he uses the concept of 'metaphysical exposition', and of, on the other hand, the implications of the fact that the representation of space as such is actually given, we are able to determine so to say a priori what the four articles of the exposition should be about. But instead of closing midst the comfort of such an a priori overview, it might be useful to get back to the first, most controversial, article of the exposition in order to show how the above, principle-guided interpretation is able to let sound a new voice in the discussion.

The objection usually raised against the first article of the exposition is that it merely contains the tautological assertion that space is required to be able to represent things as located in space, and that this tautology doesn't suffice to prove that space isn't derived empirically from the relations of outer appearances. A well known reply to this objection consists in pointing to two different meanings of the phrase "outside me", namely in the sense of 'distinct from me' and 'located in another place as myself'. Relying on this ambiguity of the phrase "outside me", the reply then states that the first article only asserts that, in order to be able to represent something as 'distinct from me' I should already necessarily be in possession of the representation of space. The core of Kant's argument would thus be, that, although as a concept, 'distinct from me' in no way analytically contains the determination 'located in another place as myself', I can actually only conceive of something as 'distinct from me' when this something is at the same time 'located in another place as myself'. In spite of the fact that the thesis of the reply, considered on its own, makes a lot of sense and seems indeed to counter the tautology-objection, ${ }^{43}$ it has to confront a simple, albeit insurmountable, problem: If Kant really wanted us to see that the representation of space is a necessary condition of outer experience because for us humans 'distinct from me' necessary, though not analytically, implies 'located in another place', why didn't he say so? Now of course one might have serious doubts about Kant's ability to make himself be understood, and it wouldn't be much of a surprise then if Kant would have us guess at what is really at stake here. But even then, if we take a closer look at the text, we see that Kant, in writing the first article, was just trying to avoid any eventually subsisting ambiguity concerning the phrase "outside of me". He indeed added between parentheses how he wanted this "outside me" to be understood: "[...] in order for certain sensations to be related to something outside me (i.e., to something in another place in space than [the one] I am finding myself in) [...]"44

43 We do not go here into the details of this answer, of which the degree of subtlety varies depending on the authors.

44 I translate the „d.i." in the German text with the Latin "i.e." and not with the English "that is", because, if it seems already improbable that Kant would have put between parentheses a passage containing the core of the argument, it would seem utterly absurd if he would have laid the pivotal point of his argument in an abbreviated "that is". 
It is clear then, that, since this interpretation cannot claim to rely on a solid textual basis, it doesn't suffice to counter the tautology-objection in a satisfactory manner. ${ }^{45}$

But does the principle-guided interpretation that we developed above give us the means to counter the tautology-objection? I think that it does so indeed. Firstly we should recall that the exposition merely analyses what is already given in our representation of space (which, as a conscious representation, is necessarily given under a concept), and that, hence, the first article only takes in account this our representation, and not space as a thing in itself. In determining how the representation of space is related to our faculty of knowledge, we learn from our given concept of space that we don't actually represent space as derived from what we represent as the matter of outer experiences, namely "certain sensations". Kant is not making any assumptions here about the way in which things are in themselves (independently of our representations of them), neither concerning space nor concerning sensation. So it is nothing less than a fact of our actual representation of space as an a priori intuition, that, when considered in regard to our faculty of knowledge, we only relate this representation of space to "outer knowledge" (what we more commonly would call 'knowledge about outer objects' or 'outer experience'), and that, within this relation, we conceive of it as form, and not as matter.

We saw, secondly, that, in analysing our representation of space with regard to outer experience, we conceive of the former as a necessary condition of the latter. Now, this also is an actual fact of our representation of space and its relation to "outer knowledge". In other words: it is the mere analysis of the modality of the givenness of our concept of space that makes clear that we actually represent space as a necessary condition of outer experience. And thus, because we have to do here with a simple fact within our representation of the relation between space and "outer knowledge", strictly speaking, this statement doesn't have to be subject to proof. So, unlike what the analysis of our representation of, say, "roundness" in relation to (the representation of) our faculty of knowledge would learn us, namely that roundness is not a necessary condition of cognition (that is: neither of "inner", nor of "outer" knowledge), the analysis of our representation of space in relation to our faculty of knowledge learns us that space, as we represent it, is, though not a condition of "inner knowledge", very well a necessarily condition of "outer knowledge". Now, that the exposition is metaphysical means that it exposes what belongs to a concept as given a priori, and when the a priori given content of our concept of space includes the representation of its being a necessary condition of outer experience, this necessity is not merely comparative, as it would be when it had been concluded from empirical data. Because the analysis of our given concept of space only uses of that what is given a priori, the necessity found by analysis is absolute with regard to our faculty of knowledge.

45 This has been argued before by Lorne Falkenstein and Daniel Warren. See respectively: Falkenstein, Lorne: Op.cit., 163-165 and Warren, Daniel: "Kant and the Apriority of Space". In: The Philosophical Review 107, 1998, 179-224. 
That means that this necessity is absolute, even if the fact that the actual disposition of our faculty of knowledge indubitably claims this necessity can be regarded as merely contingent in view of some presumed transcendent possibility of other ways of knowing. But, since we cannot represent a kind of outer experience that doesn't require the representation of space, for us the concept of such a possibility is entirely empty. 